\title{
Clopidogrel-Statin Interaction: a Missing Links
}

\author{
Zoran M. Todorovićc ${ }^{1,2}$, Nina B. Djukanović ${ }^{3}$, Slobodan D. Obradović ${ }^{4}$, \\ Dragana D. Protić ${ }^{1}$, Miodrag Č. Ostojić ${ }^{5}$ \\ ${ }^{1}$ Department of Pharmacology, Clinical Pharacology and Toxicology, Faculty of Medicine, \\ University of Belgrade, Belgrade, Serbia \\ ${ }^{2}$ University Medical Center "Bežanijska kosa", Belgrade, Serbia \\ ${ }^{3}$ High Medical School Milutin Milanković, Belgrade, Serbia \\ ${ }^{4}$ Clinic of Emergency Medicine, Military Medical Academy, Medical Faculty, University of \\ Defense, Belgrade, Serbia \\ ${ }^{5}$ Faculty of Medicine, University of Belgrade, Belgrade, Serbia
}

\section{SUMMARY}

Introduction: The use of clopidogrel is associated with a large variability in the response to this drug, wherein the results of the numerous studies indicate that even one out of three patients can be placed in the category of non responder.

Corresponding section headings: Among the many causes of modified pharmacodynamic effects of clopidogrel, special attention is addressed to the possible clopidogrel-statin interaction. Numerous studies have focused on this problem, but it still seems to be missing the right answer.

Conclusion: This paper reviews some of the most important facts regarding concomitant use of clopidogrel and statins, and specific issues to be addressed for safe treatment of patients.

Keywords: clopidogrel, resistance, statins, interaction

\section{INTRODUCTION}

Combined antiplatelet therapy with aspirin and clopidogrel is the main therapy regimen which is applied in patients with acute coronary syndromes and patients undergoing percutaneous coronary intervention [1-6]. Despite the intensive use of combination of these drugs, the occurrence of adverse cardiovascular events is still significant. Clopidogrel resistance, relative to interindividual variability of response to clopidogrel, is one of the possible reasons for that. Clinical trials have demonstrated that the relationship between inadequate response to clopidogrel and increased risk of future thrombotic events may not be ignored.

Unfortunately, the concept of clopidogrel resistance is still not fully understood, although certain potential mechanisms that may be responsible for this have been promoted $[7,8]$. They mainly include the combination of clinical, biological and genetic influences which are expressed on platelet function (Table 1) [9-11].

Among the possible mechanisms of clopidogrel resistance, drug interactions which occur on pharmacokinetic level de- 
Tabele 1. Potential mechanisms of clopidogrel resistance

\begin{tabular}{l|l|l}
\multicolumn{1}{c|}{ Clinical Factors } & \multicolumn{1}{c}{ Biological factors } & \multicolumn{1}{c}{ Genetic factors } \\
\hline - Patient non compliance & - Increased release of ADP & - Polymorphism of CYP \\
- Underdosing or nonadequate dosing & - Up regulation of the P2Y12 pathway & - Polymorphism of P2Y \\
of clopidogrel & - Up regulation of the P2Y1 pathway & \\
- Drug-drug interaction & - Up regulation of P2Y12-independent & \\
- Elevated body mass index & pathways & \\
& - Accelerated platelet turnover
\end{tabular}

serve particular attention. The role of statins in changing the pharmacodynamic effects of clopidogrel, and the level of platelet reactivity, has been reported, but remains quite controversial $[9,12-14]$.

\section{CORRESPONDING SECTION HEADINGS}

\section{Clopidogrel and statin metabolism}

Clopidogrel, which is a thienopyridine derivative, binds specifically and irreversibly to the P2Y12 receptor, thus inhibiting ADP mediated platelet aggregation. Clopidogrel is a prodrug requiring activation by the hepatic cytochrome P450 isoenzymes [15,16]. About $85 \%$ of the drug is hydrolyzed by esterases to an inactive carboxylic acid derivative [17]. The remaining part of the drug is oxidized to 2-oxo clopidogrel through a cytochrome P 450 - dependent pathway, in which CYP3A4, CYP3A5 and CYP2C19 have a greater role than the CYP2C9, CYP2B6 and CYP1A2 $[15,16,18,19]$. Hydrolysis of 2-oxo clopidogrel generates the active metabolite which contains a thiol group that binds to a cysteine on the $\mathrm{P} 2 \mathrm{Y} 12$ receptor and thus irreversibly block ADP - binding and receptor activation [20].

Any drug which inhibits cytochrome P450 (CYP) enzyme systems, may potentially

Tabele 2. Enzymes which are involved in clopidogrel and statin metabolism

\section{Drug \\ Clopidogrel

Enzymes
Main metabolic pathways:
CYP3A4, CYP3A5 and CYP2C19

Enzymes which play a less important role: CYP2C9, CYP2B6, CYP1A2

\begin{tabular}{l|l}
\hline Atorvastatin & CYP3A4 \\
\hline Simvastatin & CYP3A4 \\
\hline Lovastatin & CYP3A4 \\
\hline Fluvastatin & CYP2C9 \\
\hline Rosuvastatin & CYP2C9 and CYP2C19 (minor role) \\
\hline Pitavastatin & CYP2C9 \\
\hline Pravastatin & Non CYP
\end{tabular}

block the synthesis of the active metabolite of clopidogrel, and hence its effect on platelet function. Among these drugs, a special place takes the inhibitors of hydroxymethylglutaryl CoA reductase (HMG CoA reductase) - statins. The largest number of statins are lipophilic compounds that are subject to the process of extensive metabolism by the CYP isoenzyme systems. Atorvastatin, simvastatin and lovastatin are substrates of CYP3A4, while CYP2C9 is responsible for the metabolism of fluvastatin $[21,22]$. Rosuvastatin, although not lipophilic compound, is metabolized by CYP2C9 and to a lesser extent by CYP2C19 [23]. In contrast, the pravastatin as a hydrophilic compound, is metabolized by sulfation and not by the family of CYP enzymes (Table 2) [21].

\section{Clopidogrel-statin interaction}

CYP3A4-metabolized statins (simvastatin and atorvastatin) seems to be more potent lipidlowering drugs than pravastatin [24-26]. Such a finding could significantly affect the incidence of adverse cardiovascular outcomes.

Lau et al. were the first who have shown that the lipophilic statins are capable to inhibit CYP3A4 system and thereby reduce the formation of the active metabolite of clopidogrel, i.e. lead to a reduction of its antiplatelet effects [12]. They found that atorvastatin, in contrast to pravastatin, reduced the ability of clopidogrel to inhibit the platelet aggregation. Also, in some studies were obtained similar results with other lipophilic statins, such as simvastatin and fluvstatin [13,27]. However, in most trials is not registered that concomitant use of statins reduced clopidogrel responsiveness. Even more interesting, several researches have found that CYP3A4 metabolized statins can actually increase clopidogrel's effect on platelets [28-29]. Also, in our study, CYP3A4 metabolized statin - simvastain, didn't reduce the antiplatelet response to clopidogrel. Such response was even potentiated in comparison with the group that wasn't receiving statin (simvastatin). Only one of seven patients 


\begin{tabular}{|c|c|c|c|}
\hline Study & Population & Treatment, $\mathrm{n}$ & Results \\
\hline Lau et al. [12] & Elective $\mathrm{PCl}$ & $\begin{array}{l}\text { Atorvastatin }=19 \\
\text { Pravastatin }=9 \\
\text { No statin }=16\end{array}$ & $\begin{array}{l}\text { Atorvastatin decreases inhibi- } \\
\text { tion of platelet aggregation by } \\
\text { clopidogrel }\end{array}$ \\
\hline Neubauer et al. [13] & Elective $\mathrm{PCl}$ & $\begin{array}{l}\text { Atorvastatin }=17 \\
\text { Simvastatin }=8 \\
\text { No statin }=22\end{array}$ & $\begin{array}{l}\text { CYP3A4 statins competitively } \\
\text { inhibit the metabolic activation } \\
\text { of clopidogrel }\end{array}$ \\
\hline Serebruany et al. [31] & Elective $\mathrm{PCl}$ & $\begin{array}{l}\text { CYP3A4 statins }=37 \\
\text { Non-CYP3A4 statins }=13 \\
\text { No statin }=25\end{array}$ & $\begin{array}{l}\text { Statins do not affect the ability } \\
\text { of clopidogrel to inhibit platelet } \\
\text { function }\end{array}$ \\
\hline Trenk et al. [32] & Scheduled CA & $\begin{array}{l}\text { CYP3A4 statins }=590 \\
\text { Non-CYP3A4 statins }=123 \\
\text { No statin }=682\end{array}$ & $\begin{array}{l}\text { CYP3A4 statins have no effect } \\
\text { on the antiplatelet activity of } \\
\text { clopidogrel }\end{array}$ \\
\hline Geisler et al. [33] & Elective $\mathrm{PCl}$ & $\begin{array}{l}\text { CYP3A4 statins }=756 \\
\text { Non-CYP3A4 statins }=257 \\
\text { No statin }=142\end{array}$ & $\begin{array}{l}\text { Coadministration of statins does } \\
\text { not increase residual platelet } \\
\text { aggregation and does not worsen } \\
\text { the clinical prognosis }\end{array}$ \\
\hline Saw et al. [34] & Elective $\mathrm{PCl}$ & $\begin{array}{l}\text { CYP3A4 statins }=1001 \\
\text { Non-CYP3A4 statins }=158 \\
\text { No statin }=957\end{array}$ & $\begin{array}{l}\text { Clopidogrel benefit in reducing } \\
\text { the primary end point is similar, } \\
\text { regardless of the choice of statin }\end{array}$ \\
\hline Saw et al. [36] & High CV risk & $\begin{array}{l}\text { CYP3A4 statins }=8245 \\
\text { Non-CYP3A4 statins }=1748 \\
\text { No statin }=5496\end{array}$ & $\begin{array}{l}\text { No differences in outcomes in } \\
\text { relation to the type of statin }\end{array}$ \\
\hline Lotfi et al. [37] & ACS & $\begin{array}{l}\text { Atorvastatin }=2081 \\
\text { Pravastatin }=2081\end{array}$ & $\begin{array}{l}\text { Beneficial effects of atorvastatin } \\
\text { in reducing the primary end point } \\
\text { is independent of coadministra- } \\
\text { tion with clopidogrel }\end{array}$ \\
\hline Brophy et al. [38] & Elective $\mathrm{PCl}$ & $\begin{array}{l}\text { Atorvastatin }=727 \\
\text { No Atorvastatin }=2200\end{array}$ & $\begin{array}{l}\text { More adverse events in the group } \\
\text { prescribed atorvastatin }\end{array}$ \\
\hline
\end{tabular}

treated with both clopidogrel and statin had a bad response to clopidogrel, compared to four out of eight patients from the group that was receiving only clopidogrel [30].

Different results obtained in all of these studies are likely the consequence of the number of factors, such are: lacking of the unique protocol and method for the determination of platelet function, small sample size, noncomparative doses of statins, the time when the measurement is carried out and finally lack of baseline values of platelet aggregation before the introduction of therapy.

In any case, more important than just the results of ex vivo studies, is whether the potential clopidogrel-statin interaction has an impact on clinical outcomes (Table 3). Different studies have presented diverse results, but most of them have reported that the concomitant clopidogrel-statin use isn't associated with a higher incidence of adverse cardiovascular events.

Authors from CREDO, MITRA PLUS, CHARISMA and PROVE IT-TIMI 22 trials [32-35] didn't register that concomitant use of these drugs and clopidogrel affected the clinical end points. Study of Brophy et al. was one of the few studies that showed that the combined use of CYP3A4 metabolized statins and clopidogrel exerts adverse effects and increases the risk associated with clinical outcomes [38].

Recent studies, ACCEL-STATIN and PORTO, again actualized the issue of clopidogrel-statin interaction. Results of the ACCEL-STATIN study have indicated that in clopidogrel-treated patients with high platelet vastatin, replacing to a non CYP3A4 metabolized statin (rosuvastatin or pravastatin) caused a significant reduction in platelet reactivity and the prevalence of high platelet reactivity [39]. In PORTO trial it was observed that non CYP3A4 metabolized statin (pitavastatin) had no affect on platelet reactivity in patients who are borderline or non responders to dual antiplatelet therapy, in contrast to the atorvastatin [40]. It should be emphasized that the Pelliccia et al. find that the effect of atorvastatin is particularly pronounced in patients with high platelet reactivity, in which leads to an increment of the already increased platelet reactivity. reactivity during concomitant use with ator-
Tabele 3. Pharmacodynamic and clinical studies that investigated the potential interaction of the statin and clopidogrel

$\mathrm{PCl}$ - percutaneous coronary intervention,

CA - coronary angiography, CV - cardiovascular risk, ACS - acute coronary syndrome 


\section{CONCLUSION}

Taking into account all previously disclosed, it is clear that there are many questions which are required to be explained and based on which we could come to some strong and precious conclusion about possible influence of concomitant statin use on the variability in patient response to clopidogrel.

Perhaps the first step might be to clarify doubts regarding the lack of a unique protocol, ie. precise definition and proof method for identification of the clopidogrel resistance. Although there are more available tests for monitoring of clopidogrel therapy $[4,35]$ their routine use is not come to life yet. Considering the cost of these tests and accompanied economic expenses, maybe at the beginning, the measurement of platelet function should be limited to patients with a high risk for poor response to clopidogrel.

The absence of cleary defined doses of clopidogrel and statins is the next issue should be resolved. When it comes to doses of clopidogrel, the studies have used different doses: loading doses of 300 or $600 \mathrm{mg}$ and 75 $\mathrm{mg}$ maintenance dose. Since, it is known that clinical efficacy of clopidogrel behaves in a dose dependant manner, clinical studies that would explained potentially clopidogrel-statin interaction are still missing in the light of these facts. The situation is similar when it comes to doses of statins.

In patients undergoing percutaneous coronary intervention (PCI), time of sampling for analysis is also something that needs to be taken into account. This is not only because of clopidogrel dose (loading or maintenance dose), but also due to the impact of intervention that seems to activate platelets, causing platelet hyperreactivity within 24 hours after PCI.

In any case, it is expected that the future studies (double-blind, randomized, multicenter with a sufficient number of respondents) come up with an answer to the dilemmas that accompany the issue of possible interaction between clopidogrel and statins. Particularly in terms of the opportunities offered to patients in whom it is determines that statins reduced antithrombotic effect of clopidogrel, whether to increase the dose of clopidogrel (some initial results are not in favor of this thesis) or switch to new antiplatelet drugs.

\section{ACKNOWLEDGMENT}

This work was supported by the Ministry of Science, Republic of Serbia (Project No OI 145046) and a Grant from the Ministry of Science of Montenegro, No. 01-1370 and 01907/2.

\section{REFERENCES}

1. Task Force on Myocardial Revascularization of the European Society of Cardiology (ESC) and the European Association for Cardio-Thoracic Surgery (EACTS)1; European Association for Percutaneous Cardiovascular Interventions (EAPCI), Wijns W, Kolh P, Danchin N, Di Mario C, Falk V, Folliguet T, Garg S, Huber K, James S, Knuuti J, Lopez-Sendon J, Marco J, Menicanti L, Ostojic M, Piepoli MF, Pirlet C, Pomar JL, Reifart N, Ribichini FL, Schalij MJ, Sergeant P, Serruys PW, Silber S, Sousa Uva M, Taggart D. ESC Committee for Practice Guidelines, Vahanian A, Auricchio A, Bax J, et al. Guidelines on myocardial revascularization: The Task Force on Myocardial Revascularization of the European Society of Cardiology (ESC) and the European Association for Cardio-Thoracic Surgery (EACTS). Eur Heart J. 2010;31(20):2501-55.

2. Hamm CW1, Bassand JP, Agewall S, Bax J, Boersma E, Bueno H, Caso P, Dudek D, Gielen S, Huber K, Ohman M, Petrie MC, Sonntag F, Uva MS, Storey RF, Wijns W, Zahger D; ESC Committee for Practice Guidelines. ESC Committee for Practice Guidelines. ESC Guidelines for the management of acute coronary syndromes in patients presenting without persistent ST-segment elevation: The Task Force for the management of acute coronary syndromes (ACS) in patients presenting without persistent ST-segment elevation of the European Society of Cardiology (ESC). Eur Heart J. 2011;32(23):2999-3054.

3. Kushner FG, Hand M, Smith SC Jr, King SB 3rd, Anderson JL, Antman EM, Bailey SR, Bates ER, Blankenship JC, Casey DE Jr, Green LA, Hochman JS, Jacobs AK, Krumholz HM, Morrison DA, Ornato JP, Pearle DL, Peterson ED, Sloan MA, Whitlow PL, Williams DO; American College of Cardiology Foundation/American Heart Association Task Force on Practice Guidelines. 2009 focused updates: ACC/ AHA guidelines for the management of patients with ST-elevation myocardial infarction (updating the 2004 guideline and 2007 focused update) and ACC/AHA/SCAl guidelines on percutaneous coronary intervention (updating the 2005 guideline and 2007 focused update): a report of the American College of Cardiology Foundation/American Heart Association Task Force on practice guidelines. Circulation. 2009;120(22):2271-306.

4. Djukanovic N, Todorovic Z, Obradovic S, Njegomirovic S, Zamaklar-Trifunovic D, Protić D, Ostojic M. Clopidogrel cessation triggers aspirin rebound in patients with coronary stent. J Clin Pharm Ther. 2014;39(1):69-72.

5. Djukanovic N, Todorovic Z, Obradovic S, Zamaklar-Trifunovic D, Njegomirovic S, Milic NM, Prostran 
M, Ostojic M. Abrupt cessation of one-year clopidogrel treatment is not associated with thrombotic events. J Pharmacol Sci. 2011;117(1):12-8.

6. Obradovic S, Djukanovic N, Todorovic Z, Markovic I, Zamaklar-Trifunovic D, Protic D, Ostojic M. Men with lower HDL cholesterol levels have significant increment of soluble CD40 ligand and high-sensitivity CRP levels following the cessation of longterm clopidogrel therapy. J Atheroscler Thromb. 2015;22(3):284-92.

7. Djukanovic N, Todorovic Z, Njegomirovic S, Ostojic M, Prostran M. Advantages and limitations of clopidogrel response testing methods. Vojnosanit Pregl. 2012;69(4):353-7.

8. Grdinić A, Vojvodić D, Ilić V, Magić Z, Dukanović N, Radovanović M, Miljić P, Obradović S, Majstorović I, Cikota B, Ostojić M. The importance of tests applied to evaluate the effectiveness of antiplatelet therapy in patients with recurrent coronary stent thrombosis. Vojnosanit Pregl 2009; 66(4): 328-32.

9. Angiolillo DJ, Fernandez-Ortiz A, Bernardo E, Alfonso F, Macaya C, Bass TA, Costa MA.. Variability in individual responsiveness to clopidogrel: clinical implications, management, and future perspectives. J Am Coll Cardiol. 2007;49(14):1505-16.

10. Grdinic A, Vojvodic D, Djukanovic N, Colic M, Grdinic AG, Ignjatovic V, Majstorovic I, Ilic V, Magic Z, Obradovic S, Ostojic M, Dolijanovic SP. PCI and clopidogrel: antiplatelet responsiveness and patient characteristics. Acta Cardiol. 2011;66(3):333-40.

11. Mugoša S, Djordjević N, Djukanović N, Protić D, Bukumirić Z, Radosavljević I, Bošković A, Todorović $Z$. Factors affecting the development of adverse drug reactions to beta-blockers in hospitalized cardiac patients population. Patient Prefer Adherence 2016; 10: 1461-9.

12. Lau WC, Waskell LA, Watkins PB, Neer CJ, Horowitz K, Hopp AS, Tait AR, Carville DG, Guyer KE, Bates ER.. Atorvastatin reduces the ability of clopidogrel to inhibit platelet aggregation: a new drug-drug interaction. Circulation. 2003;107(1):32-7.

13. Neubauer H, Günesdogan B, Hanefeld C, Spiecker $M$, Mügge A. Lipophilic statins interfere with the inhibitory effects of clopidogrel on platelet function-a flow cytometry study. Eur Heart J 2003; 24(19): 1744-9.

14. Lau WC, Gurbel PA, Watkins PB, Neer CJ, Hopp AS, Carville DG, Guyer KE, Tait AR, Bates ER. Contribution of hepatic cytochrome P450 3A4 metabolic activity to the phenomenon of clopidogrel resistance. Circulation. 2004 Jan 20;109(2):166-71.

15. Clarke TA, Waskell LA. The metabolism of clopidogrel is catalyzed by human cytochrome P450 3A and is inhibited by atorvastatin. Drug Metab Dispos. 2003;31(1):53-9.

16. Pereillo JM, Maftouh M, Andrieu A, Uzabiaga MF, Fedeli O, Savi P, Pascal M, Herbert JM, Maffrand JP, Picard C. Structure and stereochemistry of the ac- tive metabolite of clopidogrel. Drug Metab Dispos. 2002;30(11):1288-95.

17. Sangkuhl K, Klein TE, Altman RB. Clopidogrel pathway.

Pharmacogenet Genomics. 2010;20(7):463-5.

18. Angiolillo DJ, Fernandez-Ortiz A, Bernardo E, Ramírez C, Cavallari U, Trabetti E, Sabaté M, Hernández R, Moreno R, Escaned J, Alfonso F, Bañuelos C, Costa MA, Bass TA, Pignatti PF, Macaya $C$. Contribution of gene sequence variations of the hepatic cytochrome P450 3A4 enzyme to variability in individual responsiveness to clopidogrel. Arterioscler Thromb Vasc Biol. 2006;26(8):1895-900.

19. Kazui M, Nishiya Y, Ishizuka T, Hagihara K, Farid NA, Okazaki O, Ikeda T, Kurihara A. Identification of the human cytochrome P450 enzymes involved in the two oxidative steps in the bioactivation of clopidogrel to its pharmacologically active metabolite. Drug Metab Dispos. 2010;38(1):92-9.

20. Ding Z, Kim S, Dorsam RT, Jin J, Kunapuli SP. Inactivation of human P2Y12 receptor by thiol reagents requires interaction with both extracellular cysteine residues, Cys 17 and Cys 270 . Blood. 2003;101(10):3908-14.

21. Corsini A, Bellosta $S$, Baetta R, Fumagalli R, Paoletti R, Bernini F. New insights into the pharmacodynamic and pharmacokinetic properties of statins. Pharmacol Ther. 1999;84(3):413-28.

22. Williams D, Feely J. Pharmacokinetic-pharmacodynamic drug interactions with $\mathrm{HMG}-\mathrm{CoA}$ reductase inhibitors. Clin Pharmacokinet. 2002;41(5):343-70.

23. White CM. A review of the pharmacologic and pharmacokinetic aspects of rosuvastatin. J Clin Pharmacol. 2002;42(9):963-70.

24. Cannon $\mathrm{CP}$, Braunwald E, McCabe $\mathrm{CH}$, Rader DJ, Rouleau JL, Belder R, Joyal SV, Hill KA, Pfeffer MA, Skene AM; Pravastatin or Atorvastatin Evaluation and Infection Therapy-Thrombolysis in Myocardial Infarction 22 Investigators. Intensive versus moderate lipid lowering with statins after acute coronary syndromes. N Engl J Med. 2004;350(15):1495-504.

25. Nissen SE, Tuzcu EM, Schoenhagen P, Brown BG, Ganz P, Vogel RA, Crowe T, Howard G, Cooper CJ, Brodie B, Grines CL, DeMaria AN; REVERSAL Investigators. Effect of intensive compared with moderate lipid-lowering therapy on progression of coronary atherosclerosis: a randomized controlled trial. JAMA. 2004;291(9):1071-80.

26. Jones PH, Davidson MH, Stein EA, Bays HE, McKenney JM, Miller E, Cain VA, Blasetto JW; STELLAR Study Group. Comparison of the efficacy and safety of rosuvastatin versus atorvastatin, simvastatin, and pravastatin across doses (STELLAR Trial). Am J Cardiol. 2003;92(2):152-60.

27. Mach F, Senouf D, Fontana P, Boehlen F, Reber G, Daali Y, de Moerloose P, Sigwart U. Not all statins interfere with clopidogrel during antiplatelet therapy. Eur J Clin Invest. 2005;35(8):476-81. 
28. Piorkowski M, Weikert U, Schwimmbeck PL, Martus P, Schultheiss HP, Rauch U. ADP induced platelet degranulation in healthy individuals is reduced by clopidogrel after pretreatment with atorvastatin. Thromb Haemost. 2004;92(3):614-20.

29. Vinholt P, Poulsen TS, Korsholm L, Kristensen SR, Hallas J, Damkier P, Mickley H. The antiplatelet effect of clopidogrel is not attenuated by statin treatment in stable patients with ischemic heart disease. Thromb Haemost. 2005;94(2):438-43.

30. Djukanovic N, Todorovic Z, Grdinic A, Vojvodic $D$, Prostran M, Ostojic M. Thienopyridine resistance among patients undergoing intracoronary stent implantation and treated with dual antiplatelet therapy: assessment of some modifying factors. J Pharmacol Sci. 2008;107(4):451-5.

31. Serebruany VL, Midei MG, Malinin Al, Oshrine BR, Lowry DR, Sane DC, Tanguay JF, Steinhubl SR, Berger PB, O'Connor CM, Hennekens CH. Absence of interaction between atorvastatin or other statins and clopidogrel. Results from the Interaction Study. Arch Intern Med. 2004;164(18):2051-7.

32. Trenk D, Hochholzer W, Frundi D, Stratz C, Valina CM, Bestehorn HP, Büttner HJ, Neumann FJ. Impact of cytochrome P450 3A4-metabolized statins on the antiplatelet effect of a $600-\mathrm{mg}$ loading dose clopidogrel and on clinical outcome in patients undergoing elective coronary stent placement. Thromb Haemost. 2008;99(1):174-81.

33. Geisler T, Zürn C, Paterok M, Göhring-Frischholz K, Bigalke B, Stellos K, Seizer P, Kraemer BF, Dippon J, May AE, Herdeg C, Gawaz M. Statins do not adversely affect post-interventional residual platelet aggregation and outcomes in patients undergoing coronary stenting treated by dual antiplatelet therapy. Eur Heart J. 2008;29(13):1635-43.

34. Saw J, Steinhubl SR, Berger PB, Kereiakes DJ, Serebruany VL, Brennan D, Topol EJ; Clopidogrel for the Reduction of Events During Observation Investigators. Lack of adverse clopidogrel-atorvastatin clinical interaction from secondary analysis of a randomized, placebo-controlled clopidogrel trial. Circulation. 2003;108(8):921-4

35. Wienbergen $\mathrm{H}$, Gitt AK, Schiele $\mathrm{R}$, Juenger C, Heer T, Meisenzahl C, Limbourg P, Bossaller C, Senges J; MITRA PLUS Study Group. Comparison of clinical benefits of clopidogrel therapy in patients with acute coronary syndromes taking atorvastatin versus other statin therapies. Am J Cardiol. 2003;92(3):285-8.

36. Saw J, Brennan DM, Steinhubl SR, Bhatt DL, Mak KH, Fox K, Topol EJ; CHARISMA Investigators. Lack of evidence of a clopidogrel-statin interaction in the CHARISMA trial. J Am Coll Cardiol. 2007;50(4):291-5.

37. Lotfi A, Schweiger MJ, Giugliano GR, Murphy SA, Cannon CP; TIMI 22 Investigators. High-dose atorvastatin does not negatively influence clinical outcomes among clopidogrel treated acute coronary syndrome patients: A Pravastatin or Atorvastatin
Evaluation and Infection Therapy-Thrombolysis in Myocardial Infarction 22 (PROVE IT-TIMI 22) analysis. Am Heart J. 2008;155(5):954-8.

38. Brophy JM, Babapulle MN, Costa V, Rinfret S. A pharmacoepidemiology study of the interaction between atorvastatin and clopidogrel after percutaneous coronary intervention. Am Heart J. 2006;152(2):263-9.

39. Park Y, Jeong YH, Tantry US, Ahn JH, Kwon TJ, Park JR, Hwang SJ, Gho EH, Bliden KP, Kwak CH, Hwang JY, Kim S, Gurbel PA. Accelerated platelet inhibition by switching from atorvastatin to a nonCYP3A4-metabolized statin in patients with high platelet reactivity (ACCEL-STATIN) study. Eur Heart J. 2012;33(17):2151-62.

40. Pelliccia F, Rosano G, Marazzi G, Vitale C, Spoletini I, Franzoni F, Speziale G, Polacco M, Greco C, Gaudio C. Pharmacodynamic comparison of pitavastatin versus atorvastatin on platelet reactivity in patients with coronary artery disease treated with dual antiplatelet therapy: The PORTO trial. Circ J. 2014;78(3):679-84. 


\title{
Interakcija između klopidogrela i statina: karika koja nedostaje
}

\author{
Zoran M. Todorović $c^{1,2}$, Nina B. Djukanovićs ${ }^{3}$, Slobodan D. Obradović ${ }^{4}$, \\ Dragana D. Protić ${ }^{1}$, Miodrag Č. Ostojić ${ }^{5}$ \\ ${ }^{1}$ Institut za farmakologiju, kliničku farmakologiju i toksikologiju, Medicinski fakultet, Univerzitet u \\ Beogradu, Beograd, Srbija \\ ${ }^{2}$ Kliničko-bolnički centar "Bežanijska kosa”, Beograd, Srbija \\ ${ }^{3}$ Visoka medicinska škola Milutin Milanković, Beograd, Srbija \\ ${ }^{4}$ Klinika za urgentnu internu medicinu, Vojnomedicinska akademija, Medicinski fakultet, Univerzitet \\ odbrane, Beograd, Srbija \\ ${ }^{5}$ Medicinski fakultet, Univerzitet u Beogradu, Beograd, Srbija
}

\section{KRATAK SADRŽAJ}

Uvod: Primena klopidogrela je povezana sa velikim varijabilnošću u odgovoru na ovaj lek, pri čemu rezultati velikog broja studija ukazuju da čak jedan od tri pacijenta može biti u kategoriji onih koji ne odgovaraju na lek.

Tema: Među brojnim uzrocima koji modifikuju farmakodinamski efekat klopidogrela, posebna pažnja se posvećuje mogućoj klopidogrel - statin interakciji. Brojne studije su bile fokusirane na ovaj problem, ali se ipak čini da još uvek nedostaje pravi odgovor.

Zaključak: U ovom radu iznete su neke od najvažnijih činjenica u vezi sa istovremenom upotrebom klopidogrela i statina, kao i specifična pitanja koja treba rešiti radi bezbednog lečenja pacijenata.

Ključne reči: klopidogrel, resistancija, statini, interakcija 